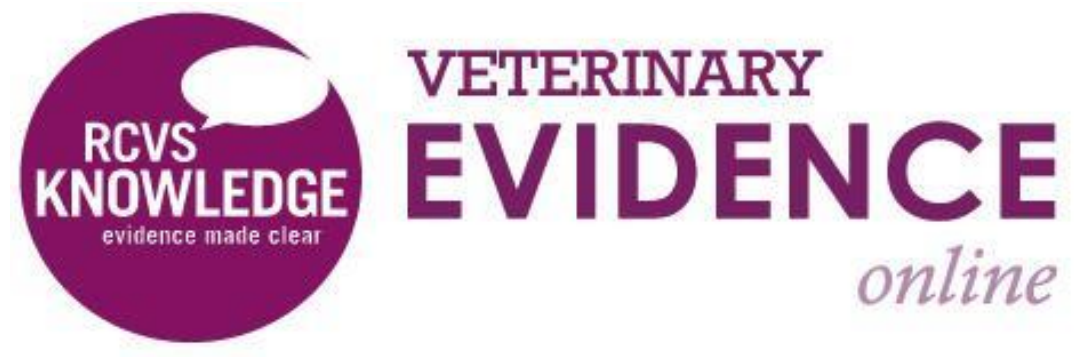

\title{
In Adult Dogs, Does Feeding a Raw Food Diet Increase the Risk of Urinary Calculi Formation Compared to Feeding a Complete Dry Kibble Diet?
}

\author{
A Knowledge Summary by \\ Emma Taylor BSc (Hons) ${ }^{1}$ \\ Nieky van Veggel MSc CBiol FHEA ${ }^{1^{*}}$
${ }^{1}$ Writtle University College \& University of Surrey School of Veterinary Medicine
*Corresponding Author (nieky.vanveggel@writtle.ac.uk)

ISSN: 2396-9776

Published: 17 Apr 2018

in: Vol 3, Issue 2

DOI: http://dx.doi.org/10.18849/ve.v3i2.155

Reviewed by: Morag Moseley (RVN DMS Cert SAN) and Sue Badger (MEd, Cert Ed, RVN) 
KNOWLEDGE SUMMARY

PICO

In adult dogs, does feeding a raw food diet alter urine composition compared to a kibble diet?

Clinical bottom line

The evidence provided by the single study identified is weak and the outcomes can neither support nor challenge the hypothesis that a raw food diet increases the risk of urinary calculi compared to a kibble diet. Therefore, professionals working within the veterinary science or nutrition field should proceed with caution when advising clients and rely on their professional experience until more evidence is generated.

\section{Clinical Scenario}

During consultation you are asked by a client if a raw food diet supports the prevention of kidney stone formation in dogs because they have read on an internet forum that a raw food diet is a healthy and natural alternative to kibble that alleviates a number of health issues. The client is now seeking additional advice from you. You decide to explore the available literature that investigates the effect of raw feeding is on urine composition in dogs.

\section{The Evidence}

There is currently very little published evidence which studies the effect of raw feeding on urine composition. The literature search returned 129 records of which 120 records were excluded because they were not related to the PICO. A further 5 records were excluded because they investigated the use of meat-meal with carbohydrate biscuit rather than raw meat, 1 record was excluded as it was non-primary research and 1 record excluded for investigating non-urinary parameters. The study by Dijcker et al., (2012) identified that currently, evidence is undetermined on whether a raw food diet maintains healthy urinary composition parameters or increases the risk or urolithiasis in adult canine dogs. The findings from this paper found that feeding a commercially available dry kibble diet was associated with a high urine calcium to creatinine $(\mathrm{Ca} / \mathrm{Cr})$ ratio compared to the raw diet which was associated with a lower $\mathrm{Ca} / \mathrm{Cr}$ ratio.

\section{Summary of the evidence}

\begin{tabular}{|r|l|}
\hline \multicolumn{2}{|l|}{ Dijcker (2012) } \\
\hline Population: & $\begin{array}{l}\text { Dogs aged between 1.3 to 16.1 years of age, } 13 \text { female (of } \\
\text { which 4 entire), } 10 \text { male (of which 4 entire), bodyweight range } \\
12-35 \mathrm{~kg} .\end{array}$ \\
\hline Sample size: & 23 \\
\hline Intervention details: & $\begin{array}{l}\text { Treatment group 1 }(\mathrm{n}=23) \text { : Fed raw food over a 4-week period } \\
\text { Treatment group 2 }(\mathrm{n}=23) \text { : complete and balanced dry } \\
\text { extruded feed over a 4-week period. Each diet started with a 3- } \\
\text { day gradual diet change, and diets were provided by owners. }\end{array}$ \\
\hline
\end{tabular}




\begin{tabular}{|c|c|}
\hline Study design: & $\begin{array}{l}\text { Cohort (study } 1 \text { ) and RCT (study } 2 \text { ) in crossover design } \\
\text { Questionnaire from private owners }\end{array}$ \\
\hline Outcome studied: & $\begin{array}{l}\text { Uox and Uca excretion rates and the dietary and animal related } \\
\text { factors which are associated with these parameters. } \\
\text { A single urine sample was collected in week } 4 \text { of the diet by the } \\
\text { owner through natural voiding. Urine sample was divided } \\
\text { immediately between a non-acidified vial and an acidified vial } \\
\text { containing } 2 \mathrm{~N} \mathrm{HCl} \text {. Samples were stored at }-20^{\circ} \mathrm{C} \text { until } \\
\text { analysis. } \\
\text { Uox was measuring using isotope dilution mass spectrometry, } \\
\text { whereas Uca was measured atomic absorption spectroscopy. }\end{array}$ \\
\hline $\begin{array}{l}\text { Main findings: } \\
\text { (relevant to PICO question): }\end{array}$ & $\begin{array}{l}\text { Uox concentration was not affected by either diet } \\
\text { Uca concentration was higher in dogs fed dry diet (TG2) } \\
\text { Urinary creatinine concentration high in dogs fed raw meat diet } \\
\text { (TG1) }\end{array}$ \\
\hline Limitations: & $\begin{array}{l}\text { - High degree of non-completers }(38 / 64) \text { with another } 3 \\
\text { dogs excluded as outliers. } \\
\text { - Small sample size }(n=23) \\
\text { - } \text { Questionnaire with high risk of bias. Inconsistencies } \\
\text { - } \text { with urine sampling by owners } \\
\text { - } \quad \text { Reliance on owners providing research diets }\end{array}$ \\
\hline
\end{tabular}

Appraisal, application and reflection

The option to feed a raw diet to dogs has grown in popularity and is now readily available commercially. Historically, there has been concern regarding excessive protein intake and the potential increase of calculi promoting substances such as calcium and uric acid (Robertson et al., 1979). This concern has been steadily increasing (Lulich et al., 1999) which has led to the association of a high protein diet with the increased risk of renal damage (Singer, 2003). Interest in the health benefits of a protein fed diet is increasing, however studies measure the relationship between protein and growth rather than welfare and health. Studies are also based on results from comparatively brief studies of less than 6 months. Furthermore, the majority of research conducted focusing on raw feeding, assesses the transmission rate of zoonotic disease and the risk this poses to human health (Joffe and Schlesinger, 2002; Strohmeyer et al., 2006; Finley, et al., 2006; Lefebvre et al., 2008).

It was noted at the British Small Animal Veterinary Association (BSAVA) 2016 Congress, that standardised information and advice is limited and not easily available to veterinarians, which reduces their ability to advise clients correctly. This lack of evidence-based peer reviewed research was addressed by Goh (2016), who found that advice concerning a raw feed diet often stems from anecdotal evidence only.

There is currently very little published evidence which studies the effects of raw feeding on urine composition and therefore on urinary calculus formation or urinary tract health. Additionally, there is still little evidencebased scientific research and a lack of feeding trials which supports the hypothesis that raw diets are a healthier or more nutritionally balanced than other diets (Michel, 2006; van Veggel \& Armstrong, 2017). 


\begin{tabular}{|r|l|}
\hline \multicolumn{2}{|l|}{ Search Strategy } \\
\hline $\begin{array}{r}\text { Databases searched and dates } \\
\text { covered: }\end{array}$ & CAB Abstracts (1973-2017), PubMed (1950-2017) \\
\hline Search terms: & $\begin{array}{l}\text { (dog OR dogs OR canine OR canines OR bitch OR bitches) AND (raw } \\
\text { OR BARF OR 'biologically appropriate raw feed' OR natural OR meat } \\
\text { OR 'raw food*' OR 'raw diet*') AND (urine and (composition or } \\
\text { analysis or constituent)) }\end{array}$ \\
\hline Dates searches performed: & \begin{tabular}{l}
$1^{\text {st }}$ June 2017 \\
\hline
\end{tabular} \\
\hline
\end{tabular}

\begin{tabular}{|c|l|l|}
\hline \multicolumn{2}{|l|}{ Exclusion / Inclusion Criteria } & \\
\hline Exclusion: & - Review Papers \\
& - Dogs under 1 year of age \\
& - Mixed diet \\
& - Non-urinary parameters \\
& - Non-peer reviewed publications \\
\hline Inclusion: & - Primary research papers \\
& - Dogs over 1 year of age \\
& - Urinary composition \\
& - Complete raw feed \\
\hline
\end{tabular}

\begin{tabular}{|c|c|c|c|c|c|c|c|}
\hline \multicolumn{8}{|c|}{ Search Outcome } \\
\hline Database & $\begin{array}{l}\text { Number } \\
\text { of } \\
\text { results }\end{array}$ & $\begin{array}{l}\text { Excluded } \\
\text { - not } \\
\text { related to } \\
\text { PICO }\end{array}$ & $\begin{array}{l}\text { Excluded - } \\
\text { non-primary } \\
\text { research }\end{array}$ & $\begin{array}{c}\text { Excluded } \\
\text { - under } 1 \\
\text { year of } \\
\text { age }\end{array}$ & $\begin{array}{c}\text { Excluded - } \\
\text { not complete } \\
\text { raw food }\end{array}$ & $\begin{array}{l}\text { Excluded - } \\
\text { non-urinary } \\
\text { composition }\end{array}$ & $\begin{array}{c}\text { Total } \\
\text { relevant } \\
\text { papers }\end{array}$ \\
\hline $\begin{array}{l}\text { Cab } \\
\text { Abstracts }\end{array}$ & 32 & 29 & 1 & 0 & 1 & 0 & 1 \\
\hline $\begin{array}{l}\text { NCBI } \\
\text { PubMed }\end{array}$ & 97 & 91 & 0 & 0 & 4 & 1 & 1 \\
\hline \multicolumn{7}{|c|}{ Total relevant papers when duplicates removed } & 1 \\
\hline
\end{tabular}


The authors declare no conflict of interest.

\section{REFERENCES}

1. Dijcker, J. C., Hagen-Plantinga, E. A., Everts, H., Bosch, G., Kema, I. P. and Hendriks, W. H. (2012) 'Dietary and animal-related factors associated with the rate of urinary oxalate and calcium excretion in dogs and cats.' The Veterinary record, 171(2) p. 46. DOI: http://dx.doi.org/10.1136/vr.100293

2. Finley, R., Reid-Smith, R., Ribble, C., Popa, M., Vandermeer, M. and Aramini, J. (2008) 'The occurrence and antimicrobial susceptibility of salmonellae isolated from commercially available canine raw food diets in three Canadian cities.' Zoonoses and Public Health, 55(8-10) pp. 462-469. DOI: http://dx.doi.org/10.1111/j.1863-2378.2008.01147.x

3. Finley, R., Reid-Smith, R. and Weese, J. S. (2006) 'Human health implications of Salmonella-contaminated natural pet treats and raw pet food.' Clinical Infectious Diseases: An Official Publication of the Infectious Diseases Society of America, 42(5) pp. 686-691. DOI: http://dx.doi.org/10.1086/500211

4. Goh, L.-M. (2016) 'BSAVA Congress 2016 - Raw food diets for dogs and cats: do we know enough?' Veterinary Record, 178 pp. 549-550.

5. Joffe, D. J. and Schlesinger, D. P. (2002) 'Preliminary assessment of the risk of Salmonella infection in dogs fed raw chicken diets.' The Canadian Veterinary Journal = La Revue Veterinaire Canadienne, 43(6) pp. 441442.

6. Lefebvre, S. L., Reid-Smith, R., Boerlin, P. and Weese, J. S. (2008) 'Evaluation of the risks of shedding Salmonellae and other potential pathogens by therapy dogs fed raw diets in Ontario and Alberta.' Zoonoses and Public Health, 55(8-10) pp. 470-480. DOI: http://dx.doi.org/10.1111/j.1863-

\subsubsection{5.x}

7. Lulich, J.P., Osborne, C.A., Thumchai, R., Lekcharoensuk, C., Ulrich, L.K., Koehler, L.A., Bird, K.A., Swanson, L.L. and Nakagawa, Y. (1999) 'Epidemiology of canine calcium oxalate uroliths.' Veterinary Clinics of North America: Small Animal Practice, 29(1) pp. 113-122. DOI: http://dx.doi.org/10.1016/S0195-5616(99)50007$\underline{7}$

8. Lunn, K. F. (2011) 'Raw Food Diets in Dogs: Concerns for Canine and Human Health.' Advances in Small Animal Medicine and Surgery, 24(2) pp. 1-2. DOI: http://dx.doi.org/10.1016/i.asams.2011.01.001

9. Michel, K. E. (2006) 'Unconventional Diets for Dogs and Cats.' Veterinary Clinics: Small Animal Practice, 36(6) pp. 1269-1281. DOI: http://dx.doi.org/10.1016/j.cvsm.2006.08.003

10. Robertson, W. G., Heyburn, P. J., Peacock, M., Hanes, F. A. and Swaminathan, R. (1979) 'The effect of high animal protein intake on the risk of calcium stone-formation in the urinary tract.' Clinical Science (London, England: 1979), 57(3) pp. 285-288. DOI: http://dx.doi.org/10.1042/cs0570285

11. Schlesinger, D. P. and Joffe, D. J. (2011) 'Raw food diets in companion animals: A critical review.' The 
Canadian Veterinary Journal, 52(1) pp. 50-54.

12. Singer, M. A. (2003) 'Dietary protein-induced changes in excretory function: a general animal design feature.' Comparative Biochemistry and Physiology Part B: Biochemistry and Molecular Biology, 136(4) pp. 785-801. DOI: http://dx.doi.org/10.1016/j.cbpc.2003.08.012

13. Strohmeyer, R. A., Morley, P. S., Hyatt, D. R., Dargatz, D. A., Scorza, A. V. and Lappin, M. R. (2006) 'Evaluation of bacterial and protozoal contamination of commercially available raw meat diets for dogs.' Journal of the American Veterinary Medical Association, 228(4) pp. 537-542. DOI: http://dx.doi.org/10.2460/javma.228.4.537

14. van Veggel, N. and Armstrong, M. (2017) 'In Dogs with Periodontal Disease Is Feeding a Complete Raw Meat Diet More Effective Than a Complete Kibble “Dental” Diet at Reducing Periodontal Disease?' Veterinary Evidence, 2(2). DOI: http://dx.doi.org/10.18849/ve.v2i2.88 


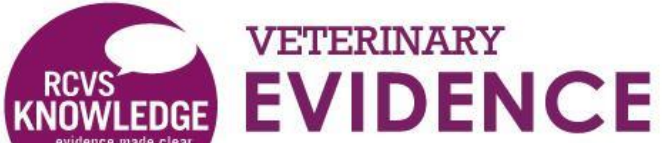 \\ ochese}

\section{Intellectual Property Rights}

Authors of Knowledge Summaries submitted to RCVS Knowledge for publication will retain copyright in their work, and will be required to grant to RCVS Knowledge a non-exclusive license of the rights of copyright in the materials including but not limited to the right to publish, re-publish, transmit, sell, distribute and otherwise use the materials in all languages and all media throughout the world, and to license or permit others to do so.

\section{Disclaimer}

Knowledge Summaries are a peer-reviewed article type which aims to answer a clinical question based on the best available current evidence. It does not override the responsibility

of the practitioner. Informed decisions should be made by considering such factors as individual clinical expertise and judgement along with patient's circumstances and owners' values. Knowledge Summaries are a resource to help inform and any opinions expressed within the Knowledge Summaries are the author's own and do not necessarily reflect the view of the RCVS Knowledge.

Veterinary Evidence and EBVM Network are RCVS Knowledge initiatives. For more information please contact us at editor@veterinaryevidence.org

RCVS Knowledge is the independent charity associated with the Royal College of Veterinary Surgeons (RCVS). Our ambition is to become a global intermediary for evidence based veterinary knowledge by providing access to information

that is of immediate value to practicing veterinary professionals and directly contributes to evidence based clinical decision-making.

www.veterinaryevidence.org

RCVS Knowledge is a registered Charity No. 230886. Registered as a Company limited by guarantee in England and Wales No. 598443.

Registered Office:

Belgravia House

62-64 Horseferry Road

London SW1P 2AF 